\title{
PENGENDALIAN KAWASAN PERMUKIMAN PERKOTAAN DI KAWASAN KONSERVASI KECAMATAN BOGOR SELATAN
}

\author{
Maskawan Siahaan ${ }^{1}$, Soekmana Soma ${ }^{2}$, Zefri $^{3}$ \\ ${ }^{1}$ Mahasiswa Pascasarjana Magister Teknik Universitas Krisnadwipayana \\ maskawan_siahaan@yahoo.com \\ 2Magister Teknik Kajian Pembangunan Perkotaan dan Wilayah Universitas Krisnadwipayana \\ pelayanan.terpadu.mt@gmail.com \\ 3Magister Teknik Kajian Pembangunan Perkotaan dan Wilayah Universitas Krisnadwipayana \\ pelayanan.terpadu.mt@gmail.com
}

\begin{abstract}
The South Bogor District which is a conservation area who has a function and the role of conservation area and land that can provide portection for the area of his men, and is the settlement with congestion low. But the development of the settlement within 10 years, from the 2007-2016 has resulted in the change in the use of the land in this area of 481,91 Ha or an average of $48.19 \mathrm{Ha}$ year. The purpose of this research is composed a strategy that needs to be done to control the develop housing area, so that the existence of a conservation are stay awake. Methods used is method superimpose and scoring then do the factors that most influential on the aberration of utilization of land. From the analysis of the level of threat is conservation areas, most of the area included in the middle classification with an area of $938.58 \mathrm{Ha}(46.55 \%)$, a high threat level of $283.30 \mathrm{Ha}(14.05 \%)$, while low threat level with an area reaching $794.26 \mathrm{Ha}$ (39.40\%). In addition, from the overlay of the spatial pattern map contained in the RTRW with the existing conditions, it shows existence land use mismatches specified in the spatial plan an area of 1,662.40 Ha or 59.77\%. The factors that cause the change in land use in this conservation area are population development, socio-economic conditions, accessibility, supervision of settlement construction, and licensing problems. Output the study of internal factors and external factors is conducted then a strategy can be done improve the supervision of development involving with communities by cracking down on violations of the utilization of space in the area that are not in accordance with the spatial plans, as well as maintain and preserve conservation areas through the housing development that environmentally.
\end{abstract}

Key Words: control, settlement, conservation area, land change

Abstrak : Kecamatan Bogor Selatan merupakan kawasan konservasi yang memiliki fungsi dan peran sebagai daerah resapan air dan tanah yang dapat memberikan perlindungan bagi kawasan bawahannya, dan merupakan kawasan permukiman dengan kepadatan rendah. Namun perkembangan kawasan permukiman dalam waktu 10 tahun, yaitu dari tahun 2007 - 2016 telah mengakibatkan perubahan penggunaan lahan di kawasan ini seluas 481,91 Ha atau rata-rata 48,91 Ha per tahun. Tujuan penelitian ini adalah menyusun strategi yang perlu dilakukan untuk mengendalikan pengembangan kawasan permukiman sehingga keberadaan kawasan konservasi tetap terjaga. Metode yang digunakan adalah metode superimpose dan pembobotan kemudian dilakukan analisis faktor-faktor yang paling berpengaruh terhadap terjadinya penyimpangan pemanfaatan lahan.

Dari hasil analisis tingkat keterancaman kawasan konservasi, sebagian besar termasuk dalam klasifikasi sedang seluas 938,58 Ha (46,55\%), tingkat ancaman tinggi seluas 283,30 Ha (14,05\%), tingkat ancaman rendah seluas 794,26 Ha (39,40\%). Selain itu dari hasil overlay peta rencana pola ruang yang dimuat dalam RTRW dengan kondisi eksisting, menunjukkan adanya ketidaksesuaian pemanfaatan lahan yang ditetapkan dalam RTRW seluas 1.205,05 Ha atau 59,77\%. Adapun faktor-faktor yang menjadi penyebab terjadinya perubahan pemanfaatan lahan di kawasan konservasi ini adalah perkembangan penduduk, kondisi sosial ekonomi, aksesibilitas, pengawasan pembangunan permukiman, dan masalah perizinan.

Dari hasil kajian faktor internal dan faktor eksternal yang dilakukan maka strategi yang perlu dilakukan untuk mengendalikan kawasan permukiman adalah dengan meningkatkan pengawasan pembangunan yang melibatkan peranserta masyarakat dengan menindak pelanggaran pemanfaatan ruang pada kawasan yang tidak sesuai dengan rencana tata ruang, serta menjaga dan melestarikan kawasan konservasi melalui pembangunan permukiman yang berwawasan lingkungan.

Kata Kunci : jurnal, naskah, panduan, penulisan 


\section{PENDAHULUAN}

Pertambahan jumlah penduduk dalam suatu kota akan berdampak kepada meningkatnya kebutuhan perumahan, namun disisi lain alam memiliki keterbatasan sehingga perlu adanya pengaturan mengenai pemanfaatan lahan perumahan. Selain itu ketersediaan lahan dan tingginya nilai lahan di suatu kota juga menjadi suatu masalah utama. Perkembangan wilayah terbangun yang timbul secara sporadis dibagian pinggiran wilayah kota merupakan fenomena yang terjadi pada kebanyakan kota besar di Indonesia. Lingkungan perumahan padat di bagian tengah kota atau kampung padat merupakan masalah perumahan yang juga perlu menjadi perhatian khusus untuk ditangani (Sujarto, 2011). Hal tersebut dilakukan karena perumahan dan permukiman merupakan salah satu sektor yang strategis dalam upaya membangun manusia Indonesia yang seutuhnya. Selain sebagai salah satu kebutuhan dasar manusia, perumahan dan permukiman, papan juga berfungsi strategis di dalam mendukung terselenggaranya pendidikan keluarga, persemaian budaya, dan peningkatan kualitas generasi di masa akan datang yang berjati diri (Sugandhy dan Hakim, 2009).

Kota Bogor merupakan salah satu wilayah dengan perkembangan tinggi di Provinsi Jawa Barat dan secara regional mempunyai keterkaitan yang erat dengan Provinsi DKI Jakarta, khususnya dalam lingkup Kawasan Jabodetabek. Sebagai salah satu hinterland Jakarta, Kota Bogor telah berkembang menjadi daerah limpahan Kota Jakarta, terutama pada sektor permukiman. Perkembangan tersebut telah pula mengancam keberadaan Kota Bogor sebagai Kawasan Jabodetabekpunjur yang memiliki fungsi sebagai daerah kawasan konservasi air dan tanah (Perpres Nomor 54 Tahun 2008).

Kecamatan Bogor Selatan sebagai salah satu Kecamatan di Kota Bogor diarahkan untuk kawasan konservasi (kawasan resapan air) karena kedudukan dan kondisi geografisnya yang memiliki banyak sumber mata air dan kawasan permukiman dengan kepadatan rendah (RTRW Kota Bogor, 2011). Dengan demikian perlu adanya pengawasan dan perlindungan terhadap kawasan ini sehingga dapat terjaga fungsinya sebagai kawasan lindung. Hal ini sesuai dengan amanat UU No. 32 Tahun 1990 tentang Pengelolaan Kawasan Lindung, bahwa kawasan resapan air digolongkan sebagai kawasan lindung yang berfungsi untuk memberikan perlindungan bagi kawasan di bawahnya.
Kawasan konservasi yang berada di Kecamatan Bogor Selatan meliputi: Kelurahan Mulyaharja, Pamoyanan, Genteng, Kertamaya, Rancamaya, Bojongkerta, dan Harjasari (Perda No. 8 Tahun 2012). Dengan demikian perlu adanya pengawasan dan perlindungan terhadap kawasan ini sehingga dapat terjaga fungsinya sebagai kawasan lindung.

Namun perkembangan kawasan permukiman di wilayah ini selalu meningkat dan telah terjadi perubahan penggunaan lahan dari lahan pertanian atau lahan terbuka lainnya, sempadan sungai menjadi kawasan perumahan dan permukiman, bahkan dari ruang terbuka hijau maupun kawasan konservasi menjadi kawasan permukiman. Perkembangan permukiman ini cenderung bersifat sporadis dan masif, yaitu dengan menyebarnya kawasan permukiman di kawasan konservasi yang menjadi potensi sumber air dan resapan, berada pada bantaran sungai serta berada pada lereng-lereng curam yang dapat menyebabkan longsor sehingga mengancam keselamatan penghuninya.

Berdasarkan data RTRW Kota Bogor Tahun 2017, bahwa di Kecamatan Bogor Selatan telah terjadi perubahan penggunaan lahan yang signifikan, yaitu dari tahun 2007-2012 luas lahan terbangun meningkat menjadi 568,58 $\mathrm{Ha}$ atau bertambah seluas 186,07 Ha (48,64\%). Kondisi tersebut menunjukkan, bahwa telah terjadi penyimpangan pemanfaatan lahan untuk kawasan permukiman, dan tentunya dapat mengancam keberadaan kawasan konservasi sehingga akan menimbulkan bencana dikemudian hari. Seharusnya Rencana Tata Ruang Wilayah menjadi pedoman atau panduan alokasi ruang agar pembangunan suatu wilayah tidak melampaui daya dukungnya (Rustiadi, et. al, 2011). Hal ini apabila tidak segera dikendalikan dan diarahkan akan menimbulkan bencana seperti berkurangnya persediaan air tanah, longsor dan banjir yang mengancam rusaknya kawasan konservasi maupun di wilayah hilirnya. Konservasi merupakan sebuah upaya untuk menjaga, melestarikan, dan menerima perubahan dan/atau pembangunan. Perubahan yang dimaksud bukanlah perubahan yang terjadi secara drastis dan serta merta, melainkan perubahan secara alami yang terseleksi. Hal tersebut bertujuan untuk tetap memelihara identitas dan sumber daya lingkungan dan mengembangkan beberapa aspeknya untuk memenuhi kebutuhan arus modernitas dan kualitas hidup yang lebih baik. Adapun tujuan dari kawasan konservasi adalah untuk mendapatkan bentuk penataan ruang 
dan arah pengelolaan kawasan konservasi yang optimal sehingga dapat meningkatkan fungsi dari kawasan lindung itu sendiri serta untuk mencegah timbulnya kerusakan lingkungan (UU No. 5 Tahun 1990).

Seiring dengan semakin banyaknya produk-produk rencana tata ruang yang telah diperdakan, dalam mekanisme pelaksanaan, terdapat didalamnya pengendalian pemanfaatan ruang yang dibutuhkan dalam mengawal implementasi Perda RTRW yang telah ditetapkan. Pengendalian pemanfaatan ruang saat ini menjadi hal yang penting untuk mengawal implementasi penataan ruang yang tertib. Hal ini sesuai dengan UU No. 26 Tahun 2007 Pasal 1 yang menjelaskan, bahwa pengendalian pemanfaatan ruang adalah upaya untuk mewujudkan tertib tata ruang.

Tujuan penelitian ini adalah sebagai berikut: 1) mengetahui tingkat ancaman bahaya terhadap rusaknya kawasan konservasi, 2) mengkaji perubahan penggunaan lahan kawasan permukiman di kawasan konservasi, 3) mengetahui perkembangan penduduk sehingga menyebabkan terjadinya perubahan penggunaan lahan untuk permukiman, 4) mengetahui terjadinya perkembangan permukiman sehingga menyebabkan penyimpangan pemanfaatan lahan di kawasan konservasi, 5) menganalisis faktorfaktor yang menyebabkan terjadinya penyimpangan pemanfaatan lahan permukiman di kawasan konservasi sehingga menjadi tidak terkendali, 6) menganalisis kesesuaian pemanfaatan lahan antara arahan RTRW dengan kondisi eksisting, dan 7) menyusun strategi yang perlu dilakukan untuk mengendalikan pengembangan kawasan permukiman sehingga keberadaan kawasan konservasi tetap terjaga.

\section{METODOLOGI}

Penelitian ini dilakukan di Kecamatan Bogor Selatan Kota Bogor, namun yang menjadi fokus dalam penelitian ini hanya tujuh kelurahan yang merupakan kawasan konservasi dengan luas 2.016,14 Ha (lihat Gambar 1). Adapun kelurahan yang termasuk dalam kawasan konservasi adalah: kelurahan Mulyaharja, Pamoyanan, Genteng, Kertamaya, Rancamaya, Bojongkerta, dan Harjasari (Perda No. 8/2012). Data yang digunakan dalam penelitian adalah peta citra landsat tahun 2007, 2012, dan tahun 2016, serta data pendukung berupa jumlah penduduk dan jumlah permukiman dalam waktu 10 tahun.

Untuk mengetahui tingkat ancaman kawasan konservasi digunakan analisis fisik yang meliputi: curah hujan, kemiringan lahan, jenis tanah, jenis batuan, dan penggunaan lahan. Sedangkan untuk mengetahui perubahan penggunaan lahan kawasan permukiman dilakukan analisis superimpose peta tahun 2007, 2012, dan 2016. Sementara untuk mengetahui perkembangan penduduk dan permukiman dilakukan analisis deskriptif, sedangkan untuk mengetahui faktor-faktor penyebab terjadinya perubahan pemanfaatan lahan dilakukan dengan menjelaskan hubungan antarvariabel yang akan diukur menjadi indikator variabel dari hasil penyebaran kuesioner. Dan untuk mengetahui kesesuaian rencana pola ruang dengan kondisi eksisting digunakan analisis superimpose peta citra tahun 2007 dengan tahun 2016, sedangkan penyusunan strategi dilakukan dengan menggunakan analisis SWOT.

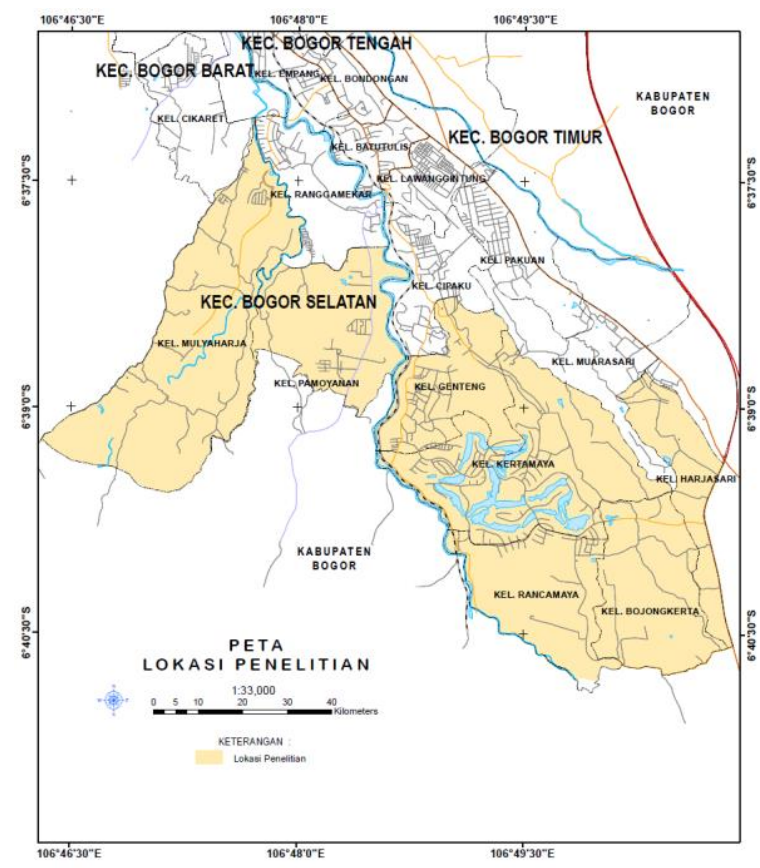

Gambar 1

Peta Lokasi Penelitian

\section{HASIL DAN PEMBAHASAN}

\section{Tingkat Ancaman Kawasan Konservasi}

Dengan berkembangnya jumlah penduduk yang selalu meningkat dalam setiap tahun maka kebutuhan lahan untuk kebutuhan lahan permukiman juga akan semakin meningkat. Disisi lain, adanya keterbatasan lahan yang tersedia sehingga terjadi perubahan pemanfaatan lahan tidak akan terhindarkan, termasuk di dalamnya perubahan pemanfaatan lahan untuk kawasan permukiman.

Dari hasil analisis superimpose peta menunjukan, bahwa sebagian besar kawasan konservasi termasuk dalam kategori tingkat 
ancaman sedang dengan luas 938,58 $\mathrm{Ha}(46,55 \%)$ yang menyebar di tujuh kelurahan yang ada, tingkat ancaman tinggi berada di tiga kelurahan dengan luas 283,30 Ha (14,05\%), yang meliputi kelurahan Mulyaharja, Pamoyanan, dan Genteng, sedangkan tingkat ancaman rendah mencapai 794,26 Ha $(39,40 \%)$ menyebar di tujuh kelurahan. Untuk selanjutnya tingkat acamaan kawasan dapat dilihat pada Gambar 2 dan Tabel 1.

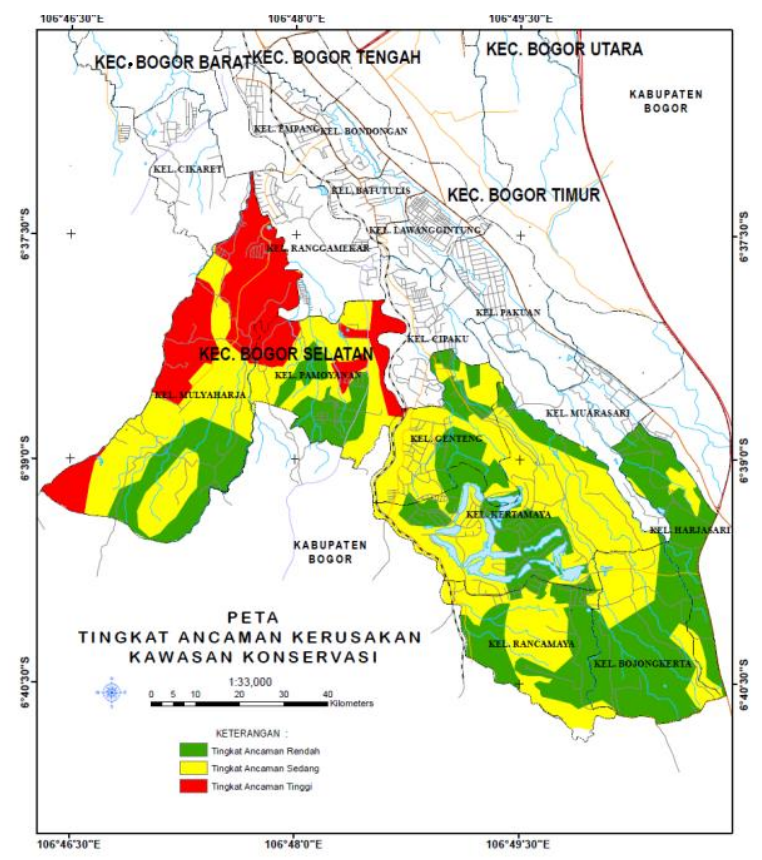

Gambar 2

Peta Tingkat Ancaman Kerusakan Kawasan Konservasi

Tabel 1 Tingkat Ancaman Kawasan Konservasi Di Wilayah Penelitian

\begin{tabular}{|c|c|c|c|}
\hline \multicolumn{4}{|c|}{ Di Wilayah Penelitian } \\
\hline No. & Kelurahan & Tingkat Ancaman & Luas (Ha) \\
\hline \multirow[t]{3}{*}{1} & \multirow[t]{3}{*}{ Kel. Mulyaharja } & Tinggi & 210,86 \\
\hline & & Sedang & 212,69 \\
\hline & & Rendah & 102,25 \\
\hline \multirow[t]{3}{*}{2} & \multirow[t]{3}{*}{ Kel. Pamoyanan } & Tinggi & 68,50 \\
\hline & & Sedang & 113,10 \\
\hline & & Rendah & 74,28 \\
\hline \multirow[t]{3}{*}{3} & \multirow[t]{3}{*}{ Kel. Genteng } & Tinggi & 3,95 \\
\hline & & Sedang & 123,65 \\
\hline & & Rendah & 77,37 \\
\hline \multirow[t]{2}{*}{4} & \multirow[t]{2}{*}{ Kel. Kertamaya } & Sedang & 272,37 \\
\hline & & Rendah & 138,82 \\
\hline \multirow[t]{2}{*}{5} & \multirow[t]{2}{*}{ Kel. Rancamaya } & Sedang & 113,61 \\
\hline & & Rendah & 114,08 \\
\hline \multirow[t]{2}{*}{6} & \multirow[t]{2}{*}{ Kel. Bojongkerta } & Sedang & 79,56 \\
\hline & & Rendah & 170,43 \\
\hline \multirow[t]{3}{*}{7} & \multirow[t]{3}{*}{ Kel. Harjasari } & Sedang & 23,62 \\
\hline & & Rendah & 117,05 \\
\hline & & Jumlah & $2.016,14$ \\
\hline
\end{tabular}

\section{Perubahan Penggunaan Lahan}

Berdasarkan data penggunaan lahan pada tahun 2007 dan 2016 dapat diambil kesimpulan, bahwa telah terjadi perubahan penggunaan lahan yang diakibatkan oleh adanya perkembangan kawasan permukiman. Kawasan permukiman mengalami peningkatan sebesar $125,99 \%$ dalam tempo 10 tahun. Sementara lahan tegalan, lahan ruang terbuka hijau, dan lahan pertanian seluruhnya mengalami penyusutan luas lahannya. Perubahan penggunaan lahan yang signifikan, terutama dari lahan tegalan ke kawasan permukiman. Dengan adanya perubahan penggunaan lahan tersebut maka luas lahan tegalan mengalami penyusutan seluas $-267,87 \mathrm{Ha}$ atau sebesar $-70,98 \%$ dalam tempo 10 tahun. Perubahan penggunaan lahan terjadi juga pada lahan pertanian dan ruang terbuka hijau menjadi lahan permukiman, sehingga terjadi penyusutan luas lahannya masing-masing seluas - 191,41 Ha $(-26,34 \%)$ dan $-22,63 \mathrm{Ha}$ (-4,27\%). Perubahan penggunaan lahan ini diakibatkan oleh semakin bertambahnya jumlah penduduk yang berdampak kepada tuntutan kebutuhan ruang bagi permukiman, sehingga memunculkan kompleksitas permasalahan yang akan mempengaruhi proses pembangunan dan perkembangan di wilayah ini. Untuk lebih jelasnya dapat dilihat pada Tabel 2 dan Gambar 3.

Tabel 2 Perubahan Penggunaan Lahan Tahun 2007-2016

\begin{tabular}{|c|c|c|c|c|c|}
\hline \multirow{2}{*}{ No. } & \multirow{2}{*}{ Penggunaan Lahan } & \multicolumn{2}{|c|}{ Luas (Ha) } & \multirow{2}{*}{$\begin{array}{c}\text { Perubahan } \\
\text { (Ha) }\end{array}$} & \multirow{2}{*}{$\%$} \\
\hline & & Tahun 2007 & Tahun 2016 & & \\
\hline & Tegalan & 377,39 & 109,52 & 267,87 & 70,98 \\
\hline 2 & Ruang Terbuka Hijau & 529,67 & 507,04 & 22,63 & 4,27 \\
\hline & Pertanian / Sawah & 726,56 & 535,15 & 191,41 & 26,34 \\
\hline 4 & Permukiman & 382,51 & 864,42 & 481,91 & 125,99 \\
\hline & Jumlah & $2.016,14$ & $2.016,14$ & & \\
\hline
\end{tabular}

Sumber : Hasil Analisis Peneliti, 2018
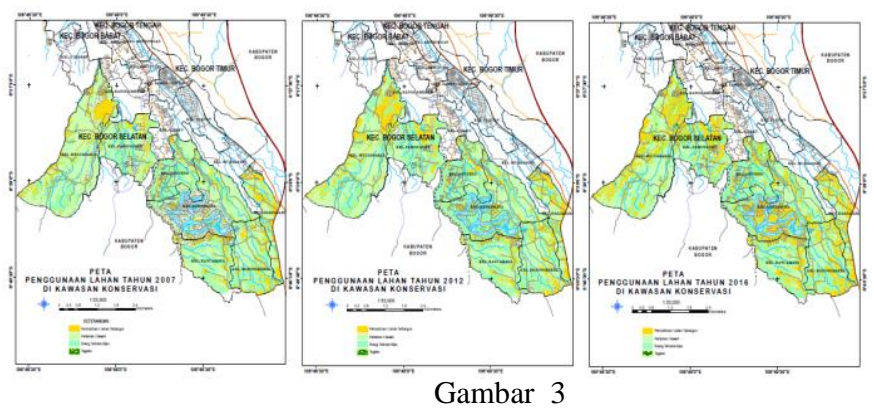

Peta Perubahan Pemanfaatan Lahan Di Kawasan Konservasi Tahun 2007 - 2016 
Dari Tabel 2, menunjukkan perubahan luas kawasan permukiman sangat signifikan dimana dalam tempo 10 tahun luasnya bertambah 481,91 Ha atau rata-rata 48,19 Ha per tahun. Dengan semakin bertambahnya luas kawasan permukiman dan tuntutan kebutuhan ruang bagi permukiman kedepannya, memunculkan kompleksitas permasalahan yang akan mempengaruhi proses pembangunan dan perkembangan di wilayah ini.

Selanjutnya dilihat dari perkembangan perubahan penggunaan lahannya telah terjadi perubahan lahan dari lahan terbuka atau bukan lahan terbangun menjadi kawasan permukiman, dimana yang paling terlihat perubahannya yaitu pada tahun 2007 sampai 2012. Perubahan lahan ini diindikasikan dengan menyusutnya lahan tegalan seluas - 97,87 Ha (- 25,93\%), sementara kawasan permukiman bertambah menjadi 186,07 Ha $(48,64 \%)$. Berkurangnya atau penyusutan luas lahan lainnya adalah lahan pertanian sebesar $74,14 \mathrm{Ha}(-10,20 \%)$, dan lahan ruang terbuka hijau sebesar - 14,06 Ha (- 2,65\%).

Sementara itu perubahan penggunaan lahan pada tahun 2012 sampai 2016 yang paling besar penyusutannya adalah lahan tegalan seluas 170,00 Ha (- 60,82 \%), diikuti oleh lahan pertanian seluas - 117,27 Ha (- 17,97\%) dan lahan ruang terbuka hijau seluas - 1,94 Ha ($0,38 \%$ ). Sementara luas kawasan permukiman bertambah seluas 295,84 Ha (52,03\%). Untuk lebih jelasnya perkembangan perubahan pemanfaatan lahan dapat dilihat pada Tabel 3 dan Gambar 4.

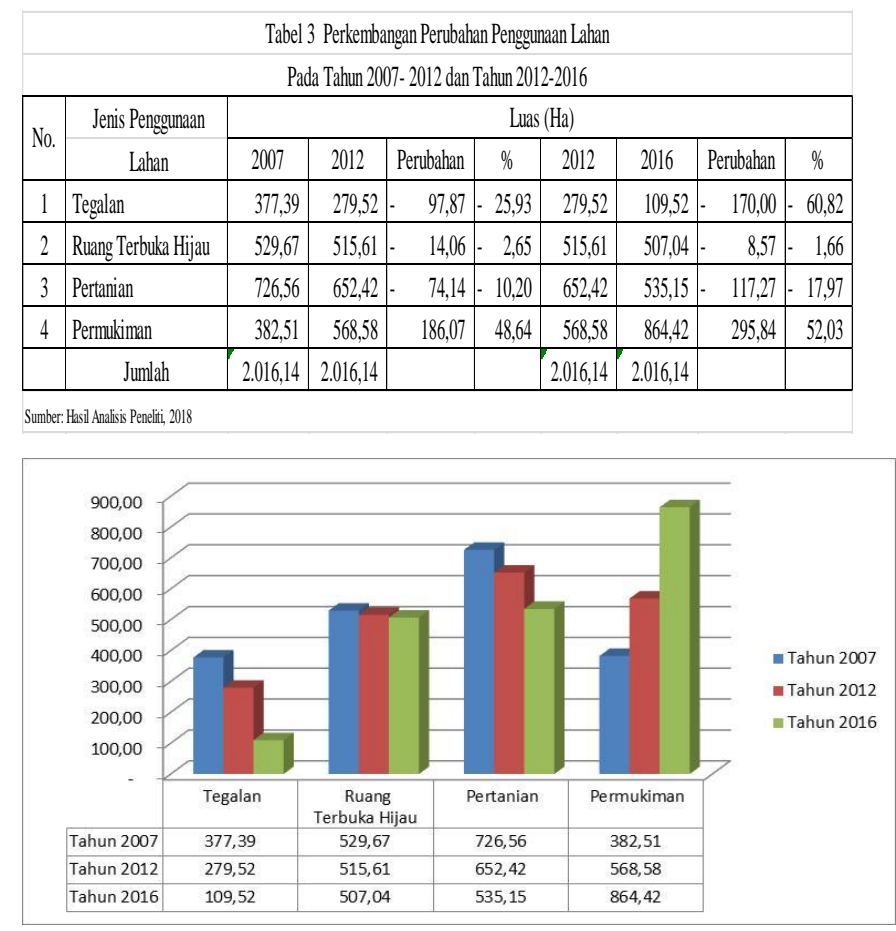

Perkembangan perubahan penggunaan lahan juga dipicu oleh aksesibilitas di wilayah penelitian yang semakin baik, misalnya: adanya jalan lingkar (ring road) yang menghubungkan kecamatan kecamatan di sekitarnya menuju stasiun atau pusat kota, dibangunnya jalan-jalan kolektor dan jalan lingkungan serta dibangunnya pusat perbelanjaan baru di wilayah perbatasan. Hal ini menyebabkan terjadinya penurunan luas penggunaan lahan tegalan atau pertanian yang dikonversi menjadi lahan terbangun, yaitu berupa permukiman dan sarana prasarana sebagai penunjang kegiatan ekonomi.

Terjadinya perubahan penggunaan lahan untuk kawasan permukiman, baik untuk permukiman baru dan sarana pendukung lainnya menyebabkan terjadinya penyimpangan pemanfaatan lahan dari rencana tata ruang yang telah ditetapkan. Hal ini dilakukan karena terdesak untuk memenuhi kebutuhan akan tempat tinggal, seperti terjadi dibeberapa kelurahan yaitu perubahan dari lahan pertanian dan lahan tegalan menjadi beberapa perumahan dan sarana lainnya. Hal tersebut dapat berdampak negatif terhadap kualitas lahan, seperti penurunan kapasitas air dalam tanah, penyerapan air (infiltrasi) berkurang sehingga terjadi aliran permukaan (run off) meningkat yang berdampak pada peningkatan erosi dan sedimentasi serta potensi banjir.

\section{Perkembangan Penduduk}

Perkembangan jumlah penduduk yang meningkat dalam setiap tahun merupakan faktor lain yang menyebabkan perubahan penggunaan lahan. Dari tahun 2007-2016 memperlihatkan perkembangan yang positif dalam setiap tahunnya dengan laju pertumbuhan sebesar 2,08\%. Laju pertumbuhan penduduk paling tinggi diperlihatkan di kelurahan Harjasari sebesar $7,49 \%$ kemudian disusul oleh kelurahan Mulyaharja sebesar 5,59\% dan kelurahan Pamoyanan sebesar 5,05\%. Sementara itu, kelurahan yang paling kecil laju pertumbuhannya adalah kelurahan Bojongkerta sebesar 1,39\% dan selebihnya memiliki laju pertumbuhan rata-rata $3,00 \%$ per tahun.

Dari jumlah dan perkembangan penduduk tersebut akan berdampak kepada kebutuhan permukiman sebagai sarana hunian sekaligus untuk bersosialisasi antar keluarga dan masyarakat di sekitarnya. Meningkatnya jumlah penduduk dan kegiatan penduduk mengakibatkan meningkatnya kebutuhan lahan. Oleh karena ketersedian lahan di dalam kota terbatas, maka 
meningkatnya kebutuhan ruang selalu akan mengambil lahan di pinggiran pusat kota (Yunus, 2005). Namun disisi lain, bahwa wilayah penelitian ini merupakan kawasan konservasi yang perlu dijaga dan dilindungi keberadaannya, serta dibatasi pengembangannya melalui kebijakan yang ada yaitu wilayah dengan kepadatan rendah. Dengan adanya keterbatasan lahan yang tersedia sementara penduduk terus meningkat maka akan berdampak terhadap perubahan pemanfaatan lahan di wilayahnya. Hal ini tentunya akan berimplikasi terhadap pemanfaatan lahan yang tidak sesuai dengan rencana pola ruang yang sudah ditetapkan oleh pemerintah Kota Bogor.

Untuk menghindari terjadinya perubahan pemanfaatan lahan yang lebih besar lagi dan dampak yang ditimbulkan oleh adanya pembangunan kawasan permukiman di kawasan konservasi, maka diperlukan strategi pemanfaatan lahan pada kawasan-kawasan yang memang masih dimungkinkan untuk menampung jumlah penduduknya. Strategi pemanfaatan lahan untuk menampung perkembangan penduduk ini dapat dilakukan dengan mengarahkan pada daerah dengan resapan air rendah, sehingga dengan konsep pengembangan ini perubahan pemanfaatan lahan yang berisiko terhadap ancaman kerusakan kawasan konservasi dapat diminimalisir. Strategi lainnya yang dapat dilakukan adalah dengan membangun sumur resapan untuk setiap rumah penduduk yang dapat diterapkan melalui kebijakan dari pemerintah Kota Bogor sebagai salah satu syarat untuk membangunan rumah kedepannya.

\section{Perkembangan Jumlah Permukiman}

Dari data yang diperoleh bahwa jumlah rumah pada tahun 2007 sebanyak 12.930 unit dan pada tahun 2012 jumlahnya meningkat menjadi 19.816 unit. Selanjutnya dalam tempo lima tahun kemudian, yaitu dari tahun 2012 - 2016 jumlahnya meningkat lagi menjadi 23.020 unit. Apabila dilihat dari proses pembangunan permukimannya lebih banyak dilakukan secara swadaya dan bertahap sesuai dengan kemampuan pembiayaan yang dimilikinya.

Berdasarkan data tersebut, perkembangan permukiman di wilayah penelitian sebagai kawasan konservasi cukup signifikan. Hal ini dapat dilihat dari laju pertumbuhan permukiman rata-rata dalam setiap tahun sebesar 7,25\%, dimana kelurahan Mulyaharja merupakan kelurahan yang memiliki laju pertumbuhan paling tinggi, yaitu sebesar 16,83\%. Laju pertumbuhan permukiman di kelurahan ini berbanding lurus dengan jumlah penduduknya yang juga memiliki laju pertumbuhan paling tinggi, yaitu 5,99\% per tahun sehingga kebutuhan permukiman dengan sendirinya akan meningkat pula. Disamping itu kelurahan Mulyaharja merupakan salah satu kelurahan yang memiliki lahan terbuka cukup luas sehingga pembangunan kawasan permukiman berkembang ke wilayah ini. Kelurahan lain yang memiliki laju pertumbuhan permukiman cukup tinggi adalah kelurahan Genteng sebesar 9,25\%, dan kelurahan Kertamaya dan kelurahan Harjasari yang masingmasing memiliki laju pertumbuhan sebesar 7,67\% dan $7,33 \%$ per tahun.

Dari analisis yang diperoleh berdasarkan hasil superimpose peta tingkat ancaman kawasan konservasi dengan peta sebaran permukiman, menunjukan bahwa permukiman yang berada di kawasan konservasi dengan ancaman tinggi mencapai luas $145,50 \mathrm{Ha}(16,83 \%)$, pada kawasan ancaman sedang dengan luas $341,97 \mathrm{Ha}$ $(39,56 \%)$, dan pada ancaman rendah seluas 376,95 Hа $(43,61 \%)$. Dari sebaran jumlah permukiman tersebut dengan tingkat ancaman tinggi paling luas di kelurahan Mulyaharja (108,76 Ha), yang berada pada kawasan dengan ancaman sedang paling luas berada di kelurahan Kertamaya (106,75). Kondisi ini mengindikasikan, bahwa keberadaan kawasan konservasi ini perlu mendapat perhatian serius dari pemerintah agar jangan sampai kawasan ini terganggu fungsinya bahkan merusak keberadaannya sehingga mengancam dan membahayakan keselamatan bagi penghuninya. Untuk lebih jelasnya sebaran permukiman dapat dilihat pada Tabel 4 dan Gambar 5.

\begin{tabular}{|c|c|c|c|c|}
\hline No. & Kelurahan & Tingkat Ancaman & Guna Lahan & Luas (Ha) \\
\hline \multirow{3}{*}{1} & \multirow[t]{3}{*}{ Kel. Mulyaharja } & Rendah & Permukiman & 28,40 \\
\hline & & Sedang & Permukiman & 62,81 \\
\hline & & Tinggi & Permukiman & 108,76 \\
\hline \multirow{3}{*}{2} & \multirow[t]{3}{*}{ Kel. Pamoyanan } & Rendah & Permukiman & 34,42 \\
\hline & & Sedang & Permukiman & 54,72 \\
\hline & & Tinggi & Permukiman & 36,74 \\
\hline \multirow{2}{*}{3} & \multirow[t]{2}{*}{ Kel. Genteng } & Rendah & Permukiman & 40,26 \\
\hline & & Sedang & Permukiman & 23,24 \\
\hline \multirow{2}{*}{4} & \multirow[t]{2}{*}{ Kel. Kertamaya } & Rendah & Permukiman & 92,26 \\
\hline & & Sedang & Permukiman & 106,75 \\
\hline \multirow{2}{*}{5} & \multirow[t]{2}{*}{ Kel. Rancamaya } & Rendah & Permukiman & 51,56 \\
\hline & & Sedang & Permukiman & 31,96 \\
\hline \multirow{2}{*}{6} & \multirow[t]{2}{*}{ Kel. Bojongkerta } & Rendah & Permukiman & 59,74 \\
\hline & & Sedang & Permukiman & 38,97 \\
\hline \multirow{3}{*}{7} & \multirow[t]{3}{*}{ Kel. Harjasari } & Rendah & Permukiman & 70,31 \\
\hline & & Sedang & Permukiman & 23,52 \\
\hline & & \multicolumn{2}{|c|}{ Jumlah } & 864,42 \\
\hline \multicolumn{5}{|c|}{ Sumber : Hasil Analisis Peneliti, 2018} \\
\hline \multicolumn{3}{|c|}{ Sebaran permukiman di Kawasan Ancaman Tinggi } & \multicolumn{2}{|c|}{$=145,50 \mathrm{Ha}(16,83 \%)$} \\
\hline \multicolumn{3}{|c|}{ Sebaran permukiman di Kawasan Ancaman Sedang } & \multicolumn{2}{|c|}{$=341,97 \mathrm{Ha}(39,56 \%)$} \\
\hline \multicolumn{3}{|c|}{ Sebaran permukiman di Kawasan Ancaman Rendah } & \multicolumn{2}{|c|}{$=376,95 \mathrm{Ha}(43,61 \%)$} \\
\hline
\end{tabular}




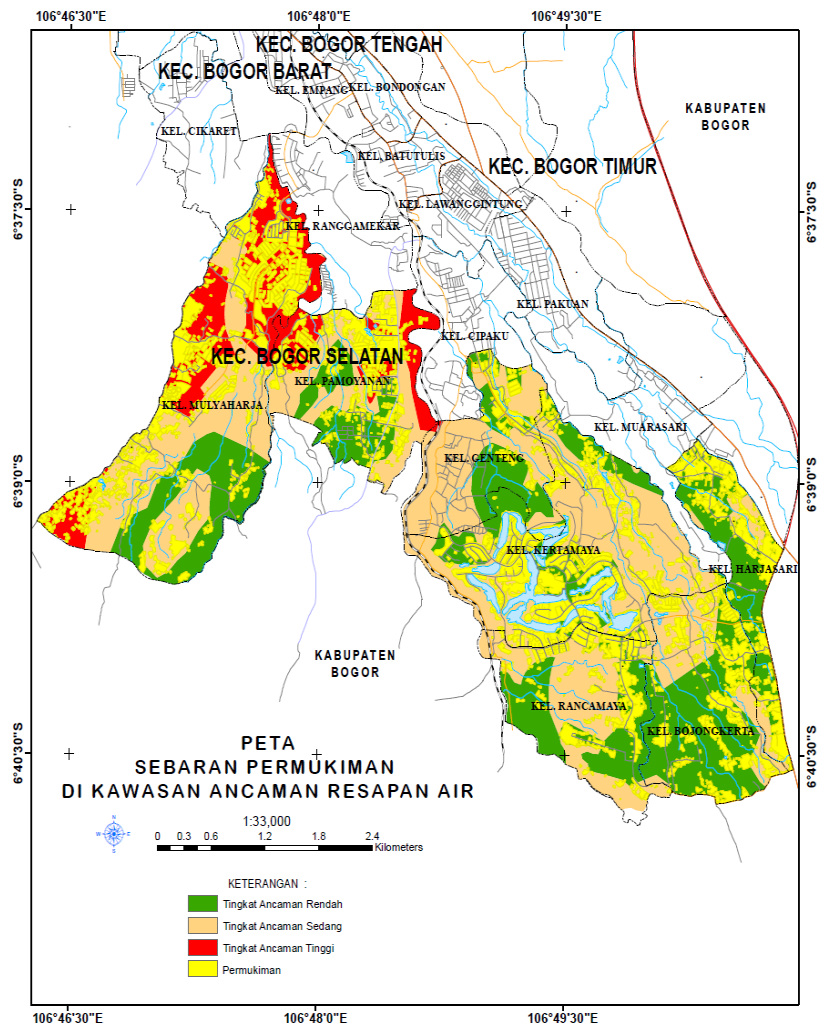

Gambar 5

Peta Sebaran Permukiman

Di Kawasan Ancaman Resapan Air

Dari data yang diperoleh menunjukkan, bahwa perkembangan lahan permukiman dari tahun 2007 - 2012 meningkat cukup signifikan sebesar $81,32 \%$ atau $16,26 \%$ per tahun dengan luas $186,07 \mathrm{Ha}$. Sementara perkembangan pada tahun 2012 - 2016 sebesar 52,03\% atau 10,41 per tahun dengan luas 295,84 Ha. Untuk lebih jelasnya dapat dilihat pada Tabel 5 dan Gambar 6.

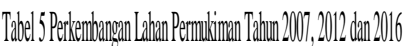

\begin{tabular}{|c|c|c|c|c|c|c|c|c|c|}
\hline \multirow{2}{*}{$\mathrm{Ab}$} & \multirow{2}{*}{ 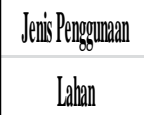 } & \multicolumn{2}{|c|}{ Llass (Ha) } & \multirow{2}{*}{$\begin{array}{l}\text { Pettamblatan } \\
\text { Lahan (Ha) }\end{array}$} & \multirow{2}{*}{$\%$} & \multicolumn{2}{|c|}{ Luas (Ha) } & Pettandalana & \multirow{2}{*}{$\%$} \\
\hline & & 20107 & 20112 & & & 2012 & 2016 & Lathan $(\mathrm{Ha})$ & \\
\hline & Pemlininana & $328,5]$ & 560,58 & 186,07 & 81,32 & 560,58 & 864,42 & 205,84 & $52,1,3$ \\
\hline
\end{tabular}

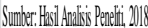

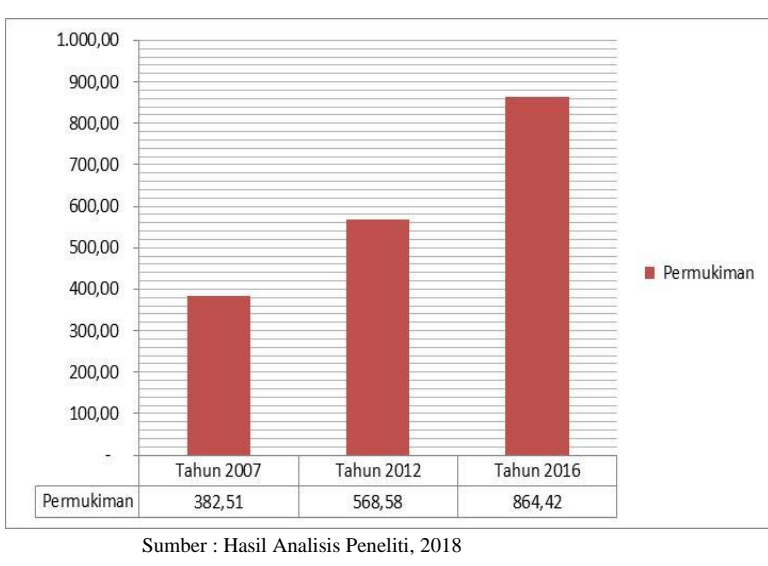

Gambar 6

Grafik Perkembangan Lahan Permukiman Tahun 2007 - 2016

Dengan kondisi perkembangan lahan permukiman ini dapat mengancam keberadaan kawasan konservasi yang ada di wilayahnya. Hal ini juga sesuai dengan perkembangan perubahan pemanfaatan lahan yang terjadi selama 10 tahun, yaitu pada tahun 2007-2016 dimana lahan permukiman mengalami peningkatan sebesar $125,99 \%$ dalam periode 10 tahun atau $12,60 \%$ per tahun.

\section{Kesesuaian Pemanfaatan Lahan}

Dari hasil superimpose peta tahun 2007 dengan peta tahun 2016 diperoleh adanya penyimpangan pemanfaatan lahan dari berbagai bentuk pemanfaatan lahan untuk kawasan permukiman atau lahan terbangun dari lahan pertanian maupun lahan terbuka lainnya.

Adapun besaran luas kesesuaian pemanfaatan lahan terbangun, yaitu $811,09 \mathrm{Ha}$ atau $40,23 \%$, sedangkan pemanfaatan lahan yang tidak sesuai mencapai $1.205,05 \mathrm{Ha}$ atau 59,77\%. Besarnya luas pemanfaatan lahan yang tidak sesuai dengan rencana tata ruang menggambarkan, bahwa kurangnya pengawasan dari aparat pemerintah Kota Bogor dan terbatasnya sumber daya manusia untuk melakukan pengawasan, terutama dari dinas terkait. Selain itu faktor perkembangan jumlah penduduk yang meningkat dalam setiap tahun dan ketersediaan lahan yang terbatas menjadi faktor penunjang, sehingga perubahan pemanfaatan lahan tidak terhindarkan. Faktor lainnya adalah kurangnya kesadaran dan pedulinya masyarakat terhadap lingkungan dan kelestarian alam. Untuk lebih jelasnya mengenai kesesuaian pemanfaatan lahan terbangun antara Rencana Tata Ruang Wilayah (RTRW) Kota Bogor dengan kondisi eksisting dapat dilihat pada Tabel 6. 


\begin{tabular}{|c|c|c|c|c|c|}
\hline \multicolumn{6}{|c|}{ Tabel 6 Tingkat Kesesuaian Rencana Pola Ruang Tahun 2010} \\
\hline \multicolumn{6}{|c|}{ Dengan Kondisi Eksisting Tahun 2016} \\
\hline \multirow{3}{*}{ No. } & \multirow{3}{*}{ Kelurahan } & \multirow{2}{*}{\multicolumn{2}{|c|}{$\begin{array}{c}\text { Kesesuaian Terhadap } \\
\text { Pola Ruang (Ha) }\end{array}$}} & \multirow{2}{*}{\multicolumn{2}{|c|}{ Prosentase $(\%)$}} \\
\hline & & & & & \\
\hline & & Sesuai & Tidak Sesuai & Sesuai & Tidak Sesuai \\
\hline 1 & Kel. Mulyaharja & 189,45 & 340,32 & 9,40 & 16,88 \\
\hline 2 & Kel. Pemayongan & 88,62 & 162,94 & 4,40 & 8,08 \\
\hline 3 & Kel. Genteng & 111,47 & 89,01 & 5,53 & 4,41 \\
\hline 4 & Kel. Kertamaya & 193,71 & 222,59 & 9,61 & 11,04 \\
\hline 5 & Kel. Rancamaya & 94,16 & 133,82 & 4,67 & 6,64 \\
\hline 6 & Kel. Bojongkerta & 74,46 & 173,99 & 3,69 & 8,63 \\
\hline \multirow[t]{2}{*}{7} & Kel. Harjasari & 59,21 & 82,38 & 2,94 & 4,09 \\
\hline & Jumlah & 811,09 & $1.205,05$ & 40,23 & 59,77 \\
\hline
\end{tabular}

Berdasarkan hasil superimpose yang telah dilakukan diperoleh gambaran bahwa lebih dari separuh wilayahnya mengalami ketidaksesuaian pemanfaatan lahan. Ketidaksesuaian atau pelang-garan pemanfaatan ruang ini telah menyalahi aturan yang sudah ditetapkan oleh pemerintah Kota Bogor sebagaimana dimuat dalam Peraturan Daerah No. 8 Tahun 2012 tentang RTRW Kota Bogor 20112031. Dalam Pasal 43 ayat (2) huruf c Perda No. 8 Tahun 2012 dijelaskan, perlunya mempertahankan kawasan resapan air untuk menjamin ketersediaan sumberdaya air dengan membatasi pengembangan kegiatan pada kawasan resapan air di kelurahan Mulyaharja, Pamoyanan, Bojongkerta, Harjasari, Rancamaya, Kertamaya dan Genteng. Dengan kondisi yang ada saat ini menunjukan, bahwa keberadaan kawasan permukiman dengan penyebarannya yang tidak terencana dan masif serta tidak adanya pengawasan dari aparat pemerintah Kota Bogor telah melanggar perda ini dan dapat mengancam fungsi dan peran keberadaan kawasan konservasi. Selain itu dengan makin berkembangnya kawasan permukiman ini dikhawatirkan akan berdampak kepada penurunan tingkat ketersediaan air tanah dan kelangsungan kawasan konservasi yang dapat menyebabkan banjir dan longsor di kawasannya maupun di wilayah hilirnya.

Wilayah-wilayah yang ditetapkan rawan terhadap bencana longsor dan banjir adalah pada kemiringan lahan diatas 30\% dan tikungan sungai Cisadane. Namun dalam kenyataannya pada kawasan sempadan sungai Cisadane telah banyak bangunan permukiman yang melanggar garis sempadan sungai (GSS).

Berdasarkan Perwali Kota Bogor No. 2 Tahun 2006 tentang garis sempadan sungai, bahwa garis sempadan sungai (GSS) Cisadane ditetapkan sepanjang $5 \mathrm{~m}$ dari kanan dan kiri tepi sungai. Sementara menurut PP No. 38 Tahun 2011 tentang Sungai pada Pasal 9, garis sempadan sungai besar tidak bertanggul di kawasan perkotaan ditentukan paling sedikit berjarak $10 \mathrm{~m}$ (sepuluh meter) dari tepi kiri dan kanan palung sungai sepanjang alur sungai. Penyimpangan pemanfaatan lahan juga terjadi akibat tidak konsistennya kebijakan pemanfaatan ruang yang sudah ditetapkan di wilayah ini, yaitu mengarahkan permukiman dengan tingkat kepadatan rendah. Namun pada kenyataannya terdapat beberapa kawasan permukiman yang memiliki kepadatan sedang yang tersebar di beberapa kawasan.

Adapun lokasi-lokasi yang memiliki ketidak-sesuaian pemanfaatan lahan paling luas berada di kelurahan Mulyaharja seluas 340,32 Ha, diikuti kelurahan Kertamaya seluas 222,59 Ha, dan Bojongkerta seluas 173,99 Ha. Penyimpangan pemanfaatan lahan di wilayah ini dikarenakan wilayahnya memiliki lahan terbuka cukup luas, baik berupa lahan pertanian dan tegalan, sehingga perkembangannya mengarah ke wilayah tersebut. Ketidaksesuaian pemanfaatan lahan terjadi juga di kelurahan Pamoyanan dan Rancamaya dengan luasan masing masing 162,94 Ha dan 133,82 Ha.

Untuk lebih jelasnya mengenai kesesuaian pemanfaatan lahan antara rencana pola ruang dengan kondisi eksisting dapat dilihat pada Gambar 7.

\section{Faktor-faktor Penyebab Terjadinya Penyimpangan Pemanfaatan Lahan}

Dari hasil analisis yang dilakukan, bahwa perkembangan jumlah penduduk mempunyai pengaruh terhadap pemanfaatan lahan. Hasil analisis menunjukan bahwa perkembangan jumlah penduduk sangat berpengaruh adalah 0.872 dengan koefisien determinasi 0,760 menunjukan, bahwa perkembangan penduduk mempengaruhi pemanfaatan lahan. $\mathrm{R}$ square yang diperoleh adalah 68,1 persen. Standard error sangat keci dibawah 1 yaitu 0,89 . Nilai observasi dari 100 responden diintegrasikan dengan observasi menjadi 5. Signifikansi F menunjukan, variabel perkembangan penduduk yang tinggi secara simultan mampu mempengaruhi perubahan pada pemanfaatan lahan. Nilai F Hitung 9,544 > F. Tabel 6,388. Hasil pengujian ini membuktikan bahwa ada pengaruh dari perkembangan penduduk terhadap pemanfaatan lahan. 


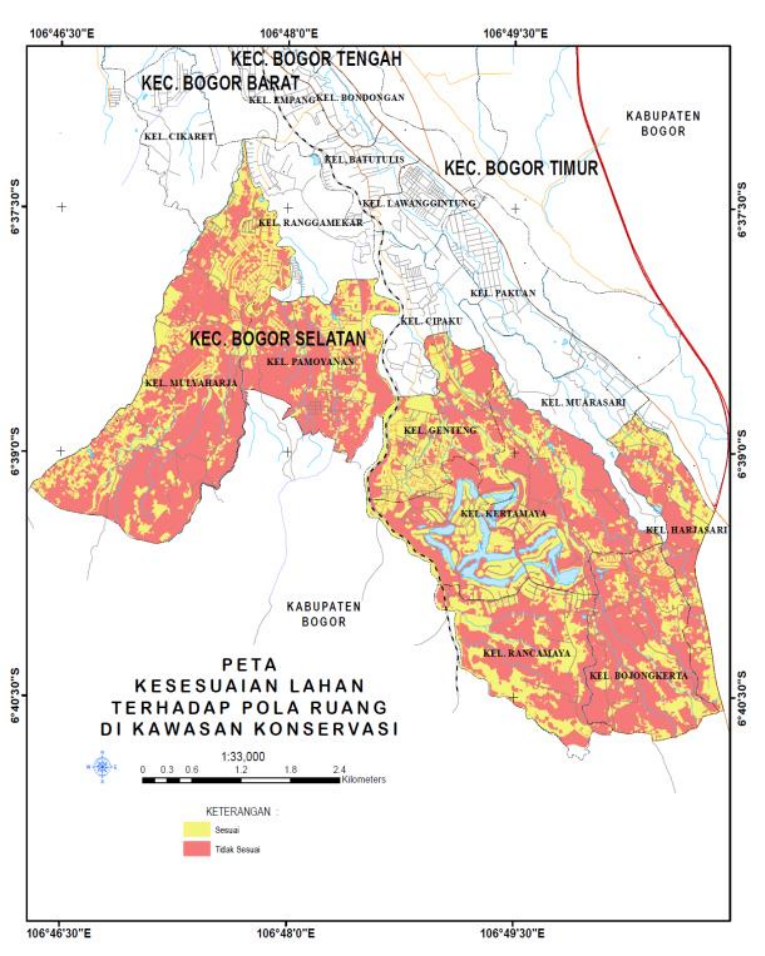

Gambar 7

Peta Kesesuaian Lahan Terhadap Pola Ruang Di Kawasan Konservasi

Selanjutnya, kondisi sosial ekonomi penduduk dari hasil statistik mempunyai pengaruh terhadap pemanfaatan lahan. Dari hasil analisis korelasi antara sosial ekonomi sangat berpengaruh adalah 0.872 dengan koefisien determinasi 0,760 menunjukan, bahwa sosial ekonomi penduduk sekitar mempengaruhi pemanfaatan lahan. $\mathrm{R}$ square yang diperoleh adalah 68,1 persen. Standard error sangat kecil dibawah 1 yaitu 0,89. Nilai observasi dari 100 responden diintegrasikan dengan observasi menjadi 5. Signifikansi F menunjukan variabel sosial ekonomi penduduk yang tinggi secara simultan mampu mempengaruhi perubahan pada pemanfaatan lahan. Nilai F Hitung 9,544 > F. Tabel 6,388. Hasil pengujian ini membuktikan, bahwa ada pengaruh dari sosial ekonomi penduduk setempat terhadap pemanfaatan lahan. Nilai pengujian tersebut hampir sama dengan nilai perkembangan penduduk.

Dari Hasil data analisis statistik aksesibilitas juga mempunyai pengaruh sangat kuat terhadap pemanfaatan lahan. Hasil analisis menunjukan aksesibilitas sangat berpengaruh adalah 0.921 dengan koefisien determinasi 0,849 menunjukan, bahwa sosial ekonomi penduduk sekitar mempengaruhi pemanfaatan lahan. $\mathrm{R}$ square yang diperoleh adalah 79,9 persen. Standard error sangat kecil dibawah 1 yaitu 0,70 .
Nilai observasi dari 100 responden diintegrasikan dengan observasi menjadi 5. Signifikansi F menunjukkan, variabel aksesibilitas yang tinggi secara simultan mampu mempengaruhi perubahan pada pemanfaatan lahan. Nilai $F$ Hitung 16,98 > F. Tabel 6,388. Hasil pengujian ini membuktikan, bahwa ada pengaruh dari aksesibilitas terhadap pemanfaatan lahan. Pertimbangan faktor aksesibilitas sangat dipertimbangkan oleh sebagian besar responden yang mengharapkan lokasi permukiman yang dekat dan relatif mudah dijangkau dengan tempat kerja. Selain itu dengan adanya ketersediaan sarana transportasi ataupun angkutan umum dapat mendukung mobilitas mereka, sehingga dapat mempercepat ke tempat tujuan, seperti terlihat dari jawaban responden yang bermukim pada wilayah penelitian. Hal ini dikarenakan sebagian besar penduduk yang ada di wilayah penelitian bekerja disektor swasta sebagai karyawan swasta, pegawai pemerintahan.

Disamping itu dari sisi kebijakan yang ada, bahwa wilayah penelitian memiliki peran dan fungsinya sebagai kawasan resapan air dan tanah, dan kawasan permukiman dengan kepadatan rendah. Penetapan fungsi ini dapat menimbulkan pengaruh yang kuat bagi perkembangan wilayah sekitarnya, terutama pertumbuhan kegiatan pada sektor yang menunjang kegiatan perdagangan dan jasa maupun perindustrian. Dari hasil data analisis kondisi fisik wilayah diketahui sangat berpengaruh terhadap pemanfaatan lahan jika dilihat tabel dibawah korelasi antara kondisi fisik wilayah sangat berpengaruh adalah 0.911 dengan koefisien determinasi 0,830 yang menunjukan, bahwa sosial ekonomi penduduk sekitar mempengaruhi pemanfaatan lahan. $\mathrm{R}$ square yang diperoleh adalah 77,4 persen. Standard error sangat kecil dibawah 1 yaitu 0,75 . Nilai observasi dari 100 responden diintegrasikan dengan observasi menjadi 5. Signifikansi F menunjukkan variabel kondisi fisik wilayah secara simultan mampu mempengaruhi perubahan pada pemanfaatan lahan. Nilai F Hitung 14,72 > F. Tabel 6,388. Hasil pengujian ini membuktikan, bahwa ada pengaruh dari kondisi fisik wilayah terhadap pemanfaatan lahan.

\section{Strategi Pengendalian Kawasan Permukiman}

Rumusan strategi pengendalian kawasan permukiman ini mempertimbangkan faktor kekuatan, kelemahan, peluang, dan ancaman yang terkait dengan pengendalian kawasan 
permukiman. Hasil analisis dari keempat faktor tersebut dapat dilihat pada Tabel 7.

\begin{tabular}{|c|c|c|}
\hline \multirow{2}{*}{ No. } & \multicolumn{2}{|c|}{ Faktor Internal } \\
\hline & Strengths (S) & Weakness (W) \\
\hline 1 & $\begin{array}{l}\text { Lokasi strategis dilewati jalur lintas } \\
\text { regional dan jalan tol }\end{array}$ & Kurangnya pengawasan dari pemerintah \\
\hline 2 & $\begin{array}{l}\text { Kondisi fisik wilayah berbukit yang } \\
\text { memiliki pemandangan yang bagus }\end{array}$ & $\begin{array}{l}\text { Daerahnya bergelombang sehingga sulit } \\
\text { dalam mengembangkan kawasannya }\end{array}$ \\
\hline 3 & $\begin{array}{l}\text { Udara kawasan masih cukup sejuk } \\
\text { membuat nyaman para penghuni }\end{array}$ & $\begin{array}{l}\text { Wilayah penelitian merupakan kawasan } \\
\text { konservasi }\end{array}$ \\
\hline 4 & $\begin{array}{l}\text { Aksesnya mudah dijangkau dan tidak } \\
\text { jauh ke pusat kota }\end{array}$ & $\begin{array}{l}\text { Adanya sungai Cisadane yang menjadi } \\
\text { pembatas pengembangan kawasan }\end{array}$ \\
\hline \multirow[t]{3}{*}{5} & $\begin{array}{l}\text { Masyarakatnya memiliki tingkat } \\
\text { kerukunan dan gotongroyongyang tinggi }\end{array}$ & $\begin{array}{l}\text { Tidak tegasnya aparat pemerintah dalam } \\
\text { menindak pelanggaran }\end{array}$ \\
\hline & \multicolumn{2}{|c|}{ Faktor Eksternal } \\
\hline & Opportunities (0) & Treaths (T) \\
\hline 1 & $\begin{array}{l}\text { Pemerintah Kota Bogor dapat } \\
\text { bekerjasama dengan investor dalam } \\
\text { pengembangan kawasan perumahan } \\
\text { yang modern tapi tetap asri }\end{array}$ & $\begin{array}{l}\text { Banyak penduduk yang bermukim di } \\
\text { sempadan sungai Cisadane sehingga } \\
\text { mengancam penurunan fungsi sungai }\end{array}$ \\
\hline 2 & $\begin{array}{l}\text { Masyarakat memiliki peranserta aktif } \\
\text { untuk membangun kawasannya dalam } \\
\text { menjaga lingkungan }\end{array}$ & $\begin{array}{l}\text { Rendahnya kesadaran masyarakat } \\
\text { terhadap lingkungan }\end{array}$ \\
\hline 3 & $\begin{array}{l}\text { Masyarakat dapat membangun peluang } \\
\text { usaha dari sektor pariwisata }\end{array}$ & $\begin{array}{l}\text { Kualitas sumber daya manusia masih } \\
\text { banyak yang rendah }\end{array}$ \\
\hline 4 & $\begin{array}{l}\text { Pengembangan kegiatan pariwisata dan } \\
\text { usaha kuliner yang dapat meningkatkan } \\
\text { pajak daerah }\end{array}$ & $\begin{array}{l}\text { Masyarakat banyak yang tidak memiliki } \\
\text { surat izin membangun }\end{array}$ \\
\hline 5 & $\begin{array}{l}\text { Adanya kebijakan untuk pengembangan } \\
\text { kawasan permukiman }\end{array}$ & $\begin{array}{l}\text { Merupakan lokasi yang rawan terhadap } \\
\text { bahaya longsor yang cukup luas }\end{array}$ \\
\hline
\end{tabular}

\section{Diagram dan Matriks SWOT}

Berdasarkan selisih jumlah skor atau nilai pengaruh unsur internal (kekuatan dan kelemahan) yaitu 3,700 - 4,000 dan selisih total nilai pengaruh unsur eksternal (peluang dan ancaman) yaitu 3,600 - 3,400 maka hasilnya adalah $(-0,30 ; 0,20)$ yang berarti posisinya berada pasa Sel 3 (lihat Gambar 8).

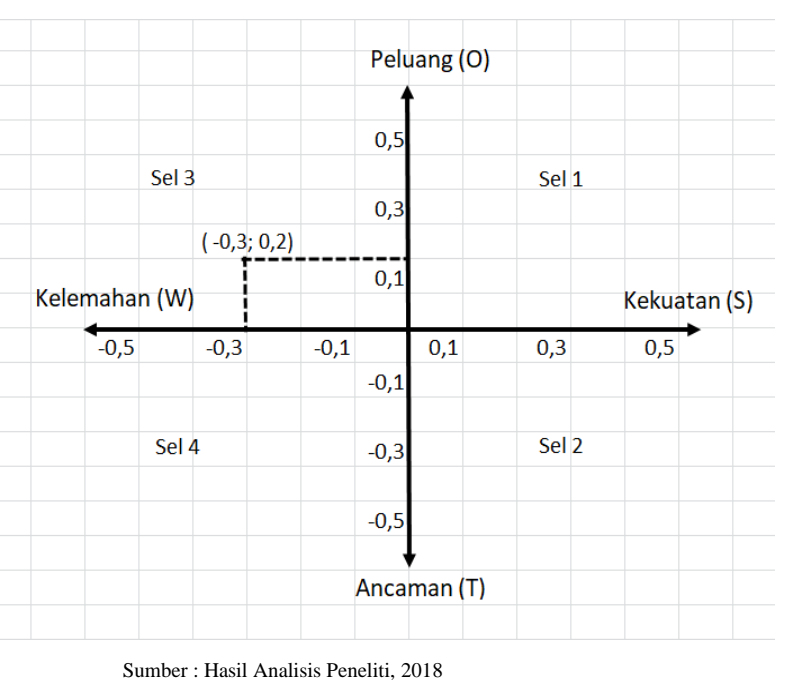

Gambar 8

Diagram SWOT Pengendalian Kawasan Permukiman
Menurut Pearce dan Robinson (1991), posisi pada sel 3 menunjukkan, bahwa pemanfaatan ruang di wilayah penelitian mempunyai situasi yang menguntungkan karena mempunyai peluang dan kelemahan. Sedangkan menurut Rangkuti (2000), posisi pada sel 3 harus menerapkan strategi WO (Weakness Opportunities). Strategi ini dilakukan dengan menggunakan kekuatan yang dimiliki untuk memanfaatkan kelemahan yang ada.

Dari uraian dan penjelasan diatas maka dapat dibuat beberapa rumusan strategi yang dapat dijadikan sebagai keputusan akhir dalam menentukan strategi pengendalian kawasan permukiman di wilayah ini. Untuk lebih jelasnya mengenai rumusan strategi seperti terlihat pada Tabel 8.

\begin{tabular}{|c|c|c|}
\hline \multirow{6}{*}{ Faktor Internal } & Kekuatan & Kelemahan \\
\hline & $\begin{array}{l}\text { S1 Lokasi strategis dilewati jalur } \\
\text { lintas regional dan jalan tol }\end{array}$ & $\begin{array}{l}\text { W1 Kurangnya pengawasan dari } \\
\text { pemerintah }\end{array}$ \\
\hline & S2 Kondisi fisik wilayah berbukit & W2 Daerahnya bergelombang \\
\hline & $\begin{array}{l}\text { S3 Udara kawasan masih cukup } \\
\text { sejuk }\end{array}$ & $\begin{array}{l}\text { W3 Wilayah penelitian merupakan } \\
\text { kawasan konservasi }\end{array}$ \\
\hline & S4 Aksesnya mudah dijangkau & $\begin{array}{l}\text { W4 Adanya sungai Cisadane sebagai } \\
\text { pembatas }\end{array}$ \\
\hline & $\begin{array}{l}\text { S5 Masyarakat memiliki } \\
\text { kerukunan dan gotongroyong }\end{array}$ & $\begin{array}{l}\text { W5 Tidak tegasnya aparat pemerintah } \\
\text { dalam menindak pelanggaran }\end{array}$ \\
\hline \multicolumn{3}{|l|}{ Faktor Eksternal } \\
\hline Peluang & Strategi SO & Strategi WO \\
\hline $\begin{array}{l}01 \text { Pemerintah dan } \\
\text { swasta dapat } \\
\text { mengembangkan } \\
\text { perumahan }\end{array}$ & \multirow{2}{*}{$\begin{array}{l}\text { Membangun kawasan perumahan } \\
\text { bernuansa asri dan nyaman } \\
\text { melalui kerjasama swasta dengan } \\
\text { pemerintah serta melibatkan peran } \\
\text { serta masyarakat dalam } \\
\text { membangun kawasannya }\end{array}$} & \multirow{2}{*}{$\begin{array}{l}\text { Meningkatkan pengawasan } \\
\text { pembangunan yang melibatkan } \\
\text { peranserta masyarakat dengan } \\
\text { menindak pelanggaran pemanfaatan } \\
\text { ruang pada kawasan yang tidak sesua } \\
\text { dengan rencana tata ruang }\end{array}$} \\
\hline $\begin{array}{l}\text { O2 Masyarakat memiliki } \\
\text { peranserta dalam } \\
\text { membangun kawasan }\end{array}$ & & \\
\hline $\begin{array}{l}\text { O3 Masyarakat dapat } \\
\text { menciptakan peluang } \\
\text { usaha }\end{array}$ & \multirow{3}{*}{$\begin{array}{l}\text { Mengembangkan sektor pariwisata } \\
\text { melalui penciptaan lapangan usaha } \\
\text { baru untuk meningkatkan pajak } \\
\text { daerah dan perekonomian } \\
\text { masyarakat }\end{array}$} & \multirow{3}{*}{$\begin{array}{l}\text { Menjaga dan melestarikan kawasan } \\
\text { konservasi melalui pembangunan } \\
\text { perumahan yang berwawasan } \\
\text { lingkungan }\end{array}$} \\
\hline $\begin{array}{l}\text { O4 Ada usaha kuliner yang } \\
\text { dapat meningkatkan } \\
\text { pajak dan ekonomi }\end{array}$ & & \\
\hline $\begin{array}{l}\text { O5 Adanya kebijakan } \\
\text { pengembangan } \\
\text { kawasan perumahan }\end{array}$ & & \\
\hline Kelemahan & Strategi ST & Strategi WT \\
\hline $\begin{array}{l}\text { T1 Permukiman banyak di } \\
\text { sempadan sungai }\end{array}$ & \multirow{3}{*}{$\begin{array}{l}\text { Mengembangkan kawasan yang } \\
\text { nyaman ditempati dengan menata } \\
\text { permukiman yang lebih teratur } \\
\text { dengan pembinaan kepada } \\
\text { masyarakatnya }\end{array}$} & \multirow{3}{*}{$\begin{array}{l}\text { Meningkatkan pengawasan } \\
\text { pembangunan dan membangun } \\
\text { kesadaran masyarakat terhadap } \\
\text { kelestarian lingkungan }\end{array}$} \\
\hline $\begin{array}{l}\text { T2 Rendahnya kesadaran } \\
\text { masyarakat }\end{array}$ & & \\
\hline $\begin{array}{l}\text { T3 Kualitas sumber daya } \\
\text { manusia masih rendah }\end{array}$ & & \\
\hline $\begin{array}{l}\text { T4 Masyarakat banyak } \\
\text { tidak memiliki surat } \\
\text { izin membangun }\end{array}$ & \multirow{2}{*}{$\begin{array}{l}\text { Membangun kawasan yang } \\
\text { nyaman melalui budaya } \\
\text { masyarakat yang taat aturan dan } \\
\text { taat hukum }\end{array}$} & \multirow{2}{*}{$\begin{array}{l}\text { Melakukan pembinaan hingga } \\
\text { peringatan terhadap pelanggaran } \\
\text { pemanfaatan ruang }\end{array}$} \\
\hline $\begin{array}{l}\text { T5 Banyak permukiman } \\
\text { tidak mematuhi aturan }\end{array}$ & & \\
\hline
\end{tabular}

Matriks SWOT menjelaskan secara rinci bagaimana peluang dan ancaman terhadap pengendalian pemanfaatan ruang untuk kawasan permukiman yang dapat disesuaikan dengan kekuatan dan kelemahan yang dimilikinya. Matriks SWOT ini menghasilkan empat sel kemungkinan alternatif strategi SO, ST, WO, dan WT.

Strategi SO yang dapat dilakukan adalah: 1) membangun kawasan perumahan bernuansa asri dan nyaman melalui kerjasama swasta dengan pemerintah serta melibatkan peran serta masyarakat dalam membangun kawasannya; 2) mengembangkan sektor pariwisata melalui 
penciptaan lapangan usaha baru untuk meningkatkan pajak daerah dan perekonomian masyarakat. Strategi WO yang dapat dilakukan adalah: 1) meningkatkan pengawasan pembangunan yang melibatkan peranserta masyarakat dengan menindak pelanggaran pemanfaatan ruang pada kawasan yang tidak sesuai dengan rencana tata ruang; 2) menjaga dan melestarikan kawasan konservasi melalui pembangunan perumahan yang berwawasan lingkungan. Sementara itu strategi ST yang dapat dilakukan antara lain membangun kawasan yang nyaman melalui budaya masyarakat yang taat aturan dan taat hukum, dan strategi WT yang dapat diterapkan antara lain meningkatkan pengawasan pembangunan dan membangun kesadaran masyarakat terhadap kelestarian lingkungan. Selanjutnya, untuk menghindari terjadinya perkembangan permukiman yang tidak terarah dan mengancam kerusakan kawasan konservasi, maka ada beberapa strategi yang perlu dilakukan sesuai dengan tingkat ancamannya. Secara keseluruhan dapat dilihat pada Tabel 9.

Tabel 9 Strategi Pengendalian Permukiman Pada Kawasan Ancaman Konservasi

\begin{tabular}{|c|c|c|c|}
\hline o. & $\begin{array}{l}\text { Ancaman } \\
\text { Tinggi }\end{array}$ & $\begin{array}{l}\text { Ancaman } \\
\text { Sedang }\end{array}$ & $\begin{array}{l}\text { Ancaman } \\
\text { Rendah }\end{array}$ \\
\hline & $\begin{array}{l}\text { Melibatkan } \\
\text { peranserta } \\
\text { masyarakat } \\
\text { dalam menjaga } \\
\text { kelestarian } \\
\text { lingkungan } \\
\text { melalui } \\
\text { penanaman } \\
\text { pohon pada } \\
\text { lahan terjal dan } \\
\text { bahaya longsor } \\
\end{array}$ & $\begin{array}{l}\text { Mensyaratkan } \\
\text { pembangunan } \\
\text { sumur resapan } \\
\text { dalam setiap 5 } \\
\text { unit rumah dengan } \\
1 \text { unit sumur yang } \\
\text { pembangunannya } \\
\text { diserahkan kepada } \\
\text { masyarakat di } \\
\text { dalam } \\
\text { kawasannya } \\
\end{array}$ & $\begin{array}{l}\text { Mengkondisikan } \\
\text { kepadatan } \\
\text { bangunan dengan } \\
\text { penjarangan antar } \\
\text { bangunan dalam } \\
\text { setiap lingkungan } \\
\text { permukiman }\end{array}$ \\
\hline & $\begin{array}{l}\text { Membangun } \\
\text { embung atau } \\
\text { danau buatan } \\
\text { sebagai tempat } \\
\text { penampungan } \\
\text { limpasan air } \\
\text { hujan guna } \\
\text { menghindari } \\
\text { gerusan tanah } \\
\text { yang akan } \\
\text { terbawa sehingga } \\
\text { mengurangi } \\
\text { terjadinya } \\
\text { longsoran }\end{array}$ & $\begin{array}{l}\text { Melakukan } \\
\text { rekayasa teknik } \\
\text { atau sistem } \\
\text { terasering untuk } \\
\text { mencegah } \\
\text { kerusakan lahan } \\
\text { dan terjadinya } \\
\text { bencana longsor } \\
\text { pada daerah } \\
\text { bergelombang } \\
\text { atau kondisi } \\
\text { topografi diatas } \\
\text { 25\%. }\end{array}$ & $\begin{array}{l}\text { Melakukan } \\
\text { sosialisasi tentang } \\
\text { bahaya bencana } \\
\text { longsor dan } \\
\text { pentingnya } \\
\text { menjaga } \\
\text { kelestarian } \\
\text { lingkungan } \\
\text { kawasannya }\end{array}$ \\
\hline & $\begin{array}{l}\text { Membatasi } \\
\text { pemanfaatan } \\
\text { lahan untuk } \\
\text { pembangunan } \\
\text { setiap bangunan } \\
\text { dengan koefisien } \\
\text { dasar bangunan } \\
\text { maksimum 20\% } \\
\text { dari luas } \\
\text { lahannya. }\end{array}$ & $\begin{array}{l}\text { Membatasi } \\
\text { pemanfaatan lahan } \\
\text { untuk } \\
\text { pembangunan } \\
\text { setiap bangunan } \\
\text { dengan koefisien } \\
\text { dasar bangunan } \\
\text { maksimum 30\% } \\
\text { dari luas lahannya. }\end{array}$ & $\begin{array}{l}\text { Membangun } \\
\text { taman-taman atau } \\
\text { ruang terbuka } \\
\text { hijau lainnya } \\
\text { untuk } \\
\text { meningkatkan } \\
\text { penyerapan air } \\
\text { dalam tanah }\end{array}$ \\
\hline
\end{tabular}

\begin{tabular}{|c|c|c|}
\hline $\begin{array}{lr}\text { Membatasi } & \\
\text { ketinggian } & \\
\text { bangunan } & \\
\text { dengan } & \\
\text { maksimum } & 2 \\
\text { lantai } & \text { atau } \\
\text { ketinggian } & \\
\text { maksimum } 14 \\
\text { meter dari dasar } \\
\text { bangunan } \\
\end{array}$ & $\begin{array}{lr}\text { Membatasi } & \\
\text { ketinggian } & \\
\text { bangunan } & \text { dengan } \\
\text { maksimum } & 2 \\
\text { lantai } & \text { atau } \\
\text { ketinggian } & \\
\text { maksimum } & 14 \\
\text { meter dari } & \text { dasar } \\
\text { bangunan } & \end{array}$ & \begin{tabular}{l}
\multicolumn{3}{l}{ Membatasi } \\
pemanfaatan \\
lahan untuk \\
pembangunan \\
setiap bangunan \\
dengan koefisien \\
dasar bangunan \\
maksimum $30 \%$ \\
dari \\
lahannya. luas \\
\end{tabular} \\
\hline
\end{tabular}

\section{PENUTUP}

\section{Simpulan}

1. Dari hasil analisis superimpose peta, tingkat ancaman kawasan konservasi sebagian besar termasuk dalam kategori sedang dengan luas 938,58 $\mathrm{Ha}(46,55 \%)$, tingkat ancaman tinggi mencapai 283,30 Ha $(14,05 \%)$, dan tingkat ancaman rendah seluas $794,26 \mathrm{Ha}(39,40 \%)$.

2. Dari tahun 2007 - 2016 terjadi perubahan pemanfaatan lahan dari lahan pertanian maupun lahan ruang terbuka lainnya menjadi lahan permukiman sebesar $23,90 \%$.

3. Perkembangan penduduk dengan laju pertumbuhan sebesar $2,08 \%$ per tahun menjadi salah satu faktor penyebab terjadinya perubahan pemanfaatan lahan.

4. Perkembangan kawasan permukiman dalam setiap tahun meningkat dengan laju pertumbuhan $7,25 \%$ per tahun sehingga menyebabkan terjadinya penyimpangan pemanfaatan lahan di kawasan konservasi.

5. Perkembangan jumlah penduduk dari hasil statistik menunjukkan punya pengaruh terhadap perubahan pemanfaatan lahan dengan nilai 0,87 , koefisien determinasi 0,76 dengan $\mathrm{R}$ square diperoleh $68,1 \%$ serta standar error sangat kecil dibawah 1 yaitu 0,89 .

6. Adanya ketidaksesuaian rencana pola ruang dalam RTRW Kota Bogor dengan kondisi eksisting dengan luasan mencapai 1.205,05 Ha yang tersebar di tujuh kelurahan yang ada meliputi: kelurahan Mulyaharja 340,32 Ha; kelurahan Pamoyanan 162,94 Ha; kelurahan Genteng 89,01 Ha; kelurahan Kertamaya 222,59 Ha; kelurahan Rancamaya 133,82 Ha; kelurahan Bojongkerta 173,99 Ha; dan kelurahan Harjasari 82,38 Ha, sedangkan yang sesuai mencapai luasan 811,09 Ha.

7. Strategi yang perlu dilakukan adalah meningkatkan pengawasan pembangunan yang melibatkan peranserta masyarakat dengan menindak pelanggaran pemanfaatan ruang pada kawasan yang tidak sesuai dengan rencana tata ruang, serta menjaga dan melestarikan kawasan konservasi melalui 
pembangunan perumahan yang berwawasan lingkungan.

\section{Saran}

1. Perlu adanya peningkatan pengawasan dan penegakkan aturan dalam pemanfaatan lahan untuk pemukiman terutama pada wilayah hulu yang mempunyai fungsi lindung. Untuk wilayah yang telah terlanjur dijadikan permukiman, perlu diminta untuk membuat sumur resapan, sedangkan pada kawasan perumahan terstruktur agar membangun danau buatan dan sejenisnya.

2. Pembangunan permukiman di kawasan dengan kondisi topografi bergelombang sebaiknya menggunakan rekayasa teknik melalui pembangunan dengan sistem terasering tanpa harus merusak lingkungan.

3. Perlunya membentuk lembaga baru pada tingkat kecamatan, seperti Dinas Pengawasan dan Penertiban Bangunan yang dapat merespon dan memutuskan secara cepat dan tepat.

4. Pemerintah perlu melakukan pemasangan papan peringatan pada kawasan yang memiliki tingkat ancaman tinggi dan pada kawasan yang rawan bencana longsor.

\section{DAFTAR PUSTAKA}

\section{Buku}

Pearce II JA, Robinson RB. 1991. Strategic Management Formulation, Implementation, and Control. Irwin Boston.

Rangkuti, F., 2000. Analisis SWOT: Teknik Membedah Kasus Bisnis, Gramedia, Jakarta.

Rustiadi, Ernan, et. al, 2011. Perencanaan dan Pengembangan Wilayah, Crestpent Press dan Yayasan Pustaka Obor Indonesia, Jakarta.

Sugandhy, Aca, dan Rustam Hakim, 2009. Prinsip Dasar Kebijakan: Pembangunan Berkelanjutan Berwawasan Lingkungan, PT. Bumi Aksara, Jakarta.

Sujarto, D., 2011. Pengembangan Kota Baru di Indonesia: Konsep dan Pola Pengelolaannya, Bunga Rampai Pembangunan Kota Indonesia Dalam Abad 21: Konsep dan Pendekatan Pembangunan Perkotaan di Indonesia, Edisi 2, URDI dan Yayasan Sugijanto Soegijoko bekerjasama dengan Lembaga Penerbit Fakultas Ekonomi Universitas Indonesia, Jakarta.

Yunus, H. S., 2005. Manajemen Kota: Perspektif Spasial, Pustaka Pelajar, Yogyakarta.

\section{Peraturan Perundang-undangan}

Peraturan Presiden No. 54 Tahun 2008 tentang Penanganan Kawasan Jakarta - Bogor Depok - Tangerang - Bekasi - Puncak Cianjur

Peraturan Pemerintah No. 38 Tahun 2011 tentang Sungai.

Peraturan Daerah No. 8 Tahun 2012 tentang RTRW Kota Bogor 2011 - 2031.

Peraturan Walikota Bogor No. 2 Tahun 2006 tentang Sempadan Sungai.

RTRW Kota Bogor Tahun 2011-2031, Bappeda, Bogor

Undang-Undang No. 26 Tahun 2007 tentang Penataan Ruang.

Undang-Undang Nomor 5 Tahun 1990 tentang Konservasi Sumber daya Alam Hayati dan Ekosistemnya. 